\title{
Application and Teaching Introspection of Japanese Honorifics in Business Correspondence
}

\author{
Shuang Qu \\ College of Foreign Languages of Aba Teachers University; Wenchuan Sichuan 623002 China
}

Keywords: business correspondence; honorifics; teaching introspection.

\begin{abstract}
In Japanese system, honorifics are a very representative and characteristic part. As for Chinese learners who study Japanese, degeneration of honorifics in modern Chinese and the asymmetry of Chinese and Japanese honorifics make it more difficult to learn Japanese honorifics. In addition, there are various problems during applying honorifics. That is to say, Japanese honorifics are important and difficult in Japanese teaching. Business Japanese is a professional course after students have certain language foundation. Therefore, learners should have a good language foundation, understand some rules in business Japanese, and accurately apply the language knowledge in business occasions. On the basis of business correspondence in Japanese enterprises, application of Japanese honorifics was analyzed by examples and application laws were summarized, which provided a reference for discussing the disadvantages of teaching.
\end{abstract}

\section{Classification of Japanese Honorifics in Business Correspondence}

\section{Example 1 TO 佃 社長様 河野専務様 琴岡部長様}

毎度お世話になります。現在、末広様案件、富士鋼業案件とバタバタとされていると 思いますが、今後の御社の方針について、一度括話を聞きたく、4月 27 日 or 28 日午後 からお時間を頂けないでしょうか?

Example 2 向s

$\mathrm{KBK}$ 碩（せき）です。展開作業をこれからょくお願いすることになりますので宜しく お願いします。

Two examples of business correspondence were selected randomly. Example 1 is 打合せ依頼 of customer company; Example 2 is 仕事の願い between colleges; No matter the content is simple or complicated and no matter the object is college or customer, it is found that Japanese honorifics are commonly used in business correspondence, and nearly every sentence includes corresponding honorifics. In Japanese, as the old saying goes, "敬語上手、商売上手", which proves one sentence we usually say during learning business Japanese, that is, honorifics are lubricating oil of interpersonal relationship. It can be seen that honorifics play an important role in business Japanese.

On the basis of grammar analysis, in above examples, there are different types of honorifics, such as "TO 佃 社長様 河野専務様 琴岡部長様", "向s", "お世話になります", "されている", " 御社", "お話を", "お時間を頂けないでしょうか", "碩です”“お願いすることになりますので ", and "宜しくお願いします". In order to provide systematic knowledge and supply convenience for study, on the basis of above-mentioned examples, Japanese honorifics in business correspondence were classified and the application rules were analyzed briefly. Three division method, the most traditional and commonly used method, was adopted.

Respect language: "様" and "s" were added to "佃 社長様 河野専務様 琴岡部長様" and " 向s" after name of person to express respect; "お世話になります" adopted the sentence pattern of expressing respect "お...になる" to express respect for customers; in "お時間を頂けないでしょう か", "頂く" is used to replace the verb of respect language "くださる" to express respect; "されて いる" is the respect expression form of "している", that is, verb of respect language; in terms of " 御社", "お話" and "お時間", "御" and "お" which are prefixes expressing respect were added before 
a noun. This almost includes the categories of honorifics in Modern Honorifics written by 奥山益朗, that is, personal pronoun, prefix, suffix and verb.

Modesty language: the expression means of modesty language in Japanese honorifics are same with respect language. However, because of the limitation of nature of business correspondence, it is limited to express modesty with personal pronoun, prefix and suffix. The scope of application of sentence form of honorifics is wide relatively. There is no example involving modesty language in above-mentioned examples, which reflects above opinions.

Solemn language: respect language directly expresses respect by raising the other side, while modesty language indirectly expresses respect by degrading oneself. Solemn language is different with respect and modesty language in terms of superior and subordinate and honorable and humble relationship. It makes interpersonal relationship be expressed more smoothly by solemn and embellishing language. "碩です" and "宜しくお願いします" express respect for the other side by using solemn language. Of course, some scholars think above-mentioned respect language such as " お話" and "お時間" can be classified to the scope of solemn language. In consideration of the application of respect prefix, they are classified to respect language temporarily, which does not affect the study in the paper.

\section{Empirical Analysis of the Application of Japanese Honorifics in Business Correspondence}

Because of the limitation of length, representative and valuable business correspondence with reference and guiding meaning were selected. According to the classification method of honorifics as mentioned before, namely, respect language, modesty language, and solemn language, it is necessary to analyze and summarize from application frequency and features. Example 1 and 2 are also investigated.

Example $3 \mathrm{KBC}$ 卿 様

お疲れ様。添付しておりますデータの展開、曲げデータ作成をお願い致します。納期 (金)。宜しくお願いします。

Example $4 \mathrm{KBK}$ 碩 様

お早う御座います

本件に関しては本当に申し訳御座いませんが、4月19日のCKCM様で行うK30改善報告 会議の準備のため、バタバタになり、4月18日のメールについて指示を忘れました。今後 こんなことが無いように、反省します。

そして、今後展開依頼がある場合、このような漏れが無いように、CCにKBCの展開図 作成者の向さんを入れていただければ、助かると思います。

宜しくお願いいたします。

Example 5 直樹専務

お疲れさまです。

本件について 着地致しました。津久田工業殿への単価 $8 ， 900$ 円にてご対応お願い 致します。懸念事項として、汎建殿の仕掛、材料在庫はありますので，何かしら言ってく ると思われます。

この度の件で小生の計算上, 汎建殿の B 142 F C 7,728 円/個です。今後のご参 考まで。

よろしくお願い致します。

First, in terms of application frequency, the application frequency of respect language is highest, followed by solemn language and modesty language. According to the classification standard mentioned before, that is, respect language, modesty language and solemn language, in above five business correspondences, respect language is used for 14 times; solemn language is used for 10 times; modesty language is used for 6 times; totaling 30 times. That is to say, honorifics are used most in all language phenomenon. Although application frequency measures the application of honorifics 
from number, high application frequency represents the importance of honorifics in business correspondence. Besides overall high application frequency, it can be seen that the application frequency of respect language is highest and that of modesty language is lowest.

Moreover, it is necessary to notice that the respect language and solemn language not only have high application frequency but also have more diversified and complicated forms. Modesty language used for 6 times includes "お願いします" or"お願いいたします".

In addition, in terms of application features, there are certain differences with business correspondence in textbooks. The form of actual correspondence is simpler than that in textbooks, and the application of honorifics is more flexible.

At the beginning, "お早う御座います" or "お疲れさまです" and even "お疲れさま" are directly used. The greetings used in general work are seldom used in textbooks of business correspondence. However, there are many greetings in actual application.

Appellation of recipients usually adopts "様" which expresses respect or "専務" and "部長" which express position. In addition, there is also "s", that is, the abbreviation of "さ $ん$ ", is seldom used in textbooks, which needs to be noted. In Example 2, corresponding to "s", self-introduction directly uses "KBK 碩（せき）です". In addition, in following work arrangement, “展開作業をこれか らよくお願いすることになりますので宜しくお願いします” rather than "宜しくお願いいた

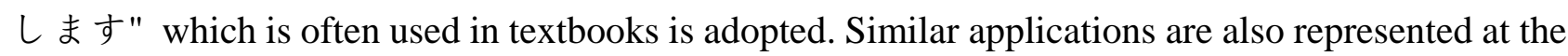
end of Example 3, "お願いします", and in the middle of Example 4, "反省します". It is clear that there are many applications. However, it is necessary to note that Example 2, 3 and 4 are mail exchanges of companies not for superiors and customers. Therefore, it is the common form used in internal correspondence and is part of business correspondence. Of course, this also reflects the principle of close and distant, inside and outside of Japanese honorifics.

\section{Teaching Introspection of Japanese Honorifics in Business Correspondence}

According to above study and analysis, it is clear that honorifics play an important role in business Japanese, as mentioned in "敬語上手は商売上手". Honorifics expression is acknowledged significance and difficulty during learning Japanese. As a learner of Japanese, it is not easy to accurately grasp the expression of honorifics and apply it in business occasions. Therefore, Japanese teachers should intensify more efforts to make students better understand the knowledge during teaching as follows.

First, it is necessary to make students have a solid language foundation. As the saying goes, the central theme remains the same. No matter in language application or examination, solid language foundation is the prerequisite of further study and improvement. The classification and corresponding application rules of Japanese honorifics are the foundation of accurately using honorifics in business Japanese. In teaching, it is necessary to make students do more exercise, differentiate the expression means of respect and modesty, gradually form a language habit, that is, from learning to acquisition. As a result, students will have a deep impression and apply the language without consideration. For example, in Example 3, "添付しておりますデータ" in "添付しておりますデータの展開、曲げデータ 作成をお願い致します"; in Example 2, "お時間を頂けないでしょうか" in " 4 月 27 日 or 28 日午後からお時間を頂けないでしょうか". I think that the goal is that students can really grasp the simple and common expression means of honorifics and apply it without too much hesitation.

Second, it is necessary to make students have a profound recognition of Japanese honorifics and business correspondence, that is, understanding corresponding cultural connotation. Language is the carrier of culture, and solid language foundation is the basic requirement for language study. Understanding of the cultural connotation of knowledge enables students to further recognize the importance of knowledge and find the interests, so as to increase the desire for active learning. Honorifics are called the lubricant of interpersonal relationship and play an important role in business activities. In business occasions, honorifics not only express respect for others, but also show the taste 
and personal training of speakers. It can be said that honorifics have become a social language in the society. Mastering honorifics in social occasions not only represent language competency but also sociability, and the basic requirement for international businessmen. If students are able to recognize that, it must promote Japanese learning.

Third, it is necessary to creatively study and apply honorifics. Investigations showed that only less than $30 \%$ of the knowledge learned in universities, especially professional knowledge, can be used in work. Of course, this mainly refers to science and engineering majors. However, this reflects the limitation of knowledge in textbooks. The writing of business correspondence and communication in business activities are actual application of Japanese, Therefore, we should not implement completely according to the standard in textbooks. Salutation "向s" in Example 2 and greetings "お疲れ様" in Example 3 are best examples. What we learn in classes are theoretical knowledge and it is necessary to creatively study and apply and continue to learn in practice.

\section{References}

[1]. Okuyama masuro. Contemporary Honorifics Dictionary. ToukyoDo Press, 1982

[2]. Okuyama masuro. Human relations etiquette. Tokyo gyosei 1978.

[3]. Jin Jingyu. Selection of Honorifics in Business Language, International Business Research, 2006

[4]. Li Xiaoying, Application Principle of Honorifics in Business Japanese, Teaching of Forestry Region, 2009

[5]. Lu Jiawen, Investigation of Japanese Honorifics Application in Business Occasions, The Border Economy and Culture, 2012 